\title{
THE RELATIONSHIP BETWEEN COMMUNITY KNOWLEDGE WITH STIGMA ON LEPROSY DISEASE IN SAMARINDA CITY
}

\author{
Ruth Putri E.S. ${ }^{1}$, Vera Madonna L. Toruan², Yuniati ${ }^{3}$ \\ ${ }^{1}$ Medical Study Program, Faculty of Medicine, Mulawarman University \\ ${ }^{2}$ Laboratory of Dermatology and Venerology, Faculty of Medicine, Mulawarman University \\ ${ }^{3}$ Laboratory of Microbiology, Faculty of Medicine, Mulawarman University \\ Email : ruthptri@gmail.com
}

\begin{abstract}
Leprosy is a chronic disease caused by Mycobacterium leprae (M. leprae) that first affects the peripheral nervous system, then the skin, and to other organs except the central nervous system. The stigma in leprosy is an obstacle to case finding and handling leprosy. Stigma is social and causes people affected by leprosy to be excluded from their social activities. There are several factors that support the stigma of leprosy, one of them is community knowledge. This research aims to study the relationship between community knowledge and stigma of leprosy in Samarinda City. This research was an analytic observational study with a cross sectional design. Data collection was carried out with the contribution of 4 Public Health Center in Samarinda City and was done by spreading questionnaires to the community using purposive sampling technique. The results of the study obtained 100 respondents who met the inclusion and exclusion criteria with detailed; poor knowledge as many as 22 respondents, sufficient knowledge as many as 49 respondents, and good knowledge as many as 29 respondents; good stigma of 24 respondents, moderate stigma of 62 respondents, and bad stigma of 14 respondents. The data was analysed using Somer's $d$ test resulting $p$ value $=0.456$; So it can be concluded that there was no relationship between community knowledge and stigma of leprosy in Samarinda City.
\end{abstract}

Keywords: community knowledge, stigma, leprosy, Samarinda City

\section{INTRODUCTION}

Leprosy is a disease caused by Mycobacterium leprae infection. These leprosy bacteria are aerobic bacteria, do not form spores, are rod-shaped, surrounded by waxy cell membranes which are characteristic of the Mycobacterium species, live in cells and are acidresistant and gram-positive. Leprosy attacks various parts of the body including nerves and skin (1). Leprosy is a disease that is found in developing countries. Leprosy generally occurs due to the limited ability of the country to provide adequate services in the fields of health, education, and social welfare to the community ${ }^{(2)}$.

World Health Organization explained that, the prevalence of leprosy that was registered globally at the end of 2015 was 176,176 cases with the number of new cases reported globally during 2015 being 211,973 (0.21 new cases per 10,000 people). The number of new cases 
decreased from 2014 to 213,899 cases and in 2013 there were 215,656 cases. The decrease in the number of new cases still places Indonesia in the top three countries with the highest number of leprosy cases in the world after India and Brazil ${ }^{(3)}$.

The Ministry of Health of the Republic of Indonesia states in Indonesia alone the number of new cases of leprosy is 10,477 cases (4.00 cases per 100,000 population) with the top three provinces having the most cases are East Java, West Java, and South Sulawesi. This number has decreased from the previous year with a number of new cases of 16,826 cases ( 6.50 cases per 100,000 population). East Kalimantan Province recorded 153 new cases in $2017^{(4)}$.

Historically, leprosy is a disease that is feared by families and communities. In ancient times spontaneous isolation has occurred because sufferers feel inferior and ashamed. People stay away from leprosy patient because of lack of knowledge or understanding as well as mistaken belief in leprosy ${ }^{(5)}$. People who lack information consider leprosy as a curse. One of the perceptions about leprosy is hereditary disease, due to witchcraft, due to sex during menstruation, wrong eating, to a highly contagious and incurable disease ${ }^{(6)}$.

Lawrence Green in Notoatmodjo said that knowledge is one of the predisposing factors for the formation of behavior. The stigma of leprosy can be influenced by social, economic, racial, cultural, cultural customs and lifestyle of the community itself. Bad stigma and discrimination against leprosy are not only done by people who do not have enough knowledge about leprosy, but can also be done by health workers. Stigma and discrimination are still inherent in people affected by leprosy that make them excluded in the lives of our people ${ }^{(7,8)}$.

Based on the above, the lack of knowledge about leprosy still causes bad stigma in the community. There are several studies conducted in Indonesia, but researchers have not found similar studies in East Kalimantan, especially the city of Samarinda. That is why researchers are interested in researching the relationship between public knowledge and the stigma of leprosy in Samarinda City.

\section{MATERIAL AND METHOD}

This study was an observational analytic study with a cross-sectional approach conducted at four Public Health Centers in Samarinda City at the end of April 2019. The inclusion criteria in this study were individuals aged 20-60 years around the working area of the public health center in the city of Samarinda, willing to be a research sample, can read, and individuals do not suffer from leprosy. The exclusion criterion in this study is that individuals are in a state of illness so it is difficult to answer research questions, and individuals are not cooperative. Data is collected by questionnaire containing questions related to the variables studied. Data processing and analysis using Microsoft Office Word 2016, Microsoft Office Excel 2016 and SPSS Statistics 24. This study has received ethical approval from the Medical Research Ethics Committee of the Medical Faculty of Mulawarman University with letter number 58 / KEPK-FK / IV / 2019. 


\section{RESULTS AND DISCUSSION}

This research was conducted in 4 Public Health Center in Samarinda located in the districts of Segiri, Temindung, Mangkupalas, and Juanda, with a total of 100 respondents. The results of the study include the characteristics of public knowledge and the characteristics of stigma against leprosy. The results of this study can be seen in table 1 and table 2. In this study, the majority of respondents with a high school / vocational high school education had sufficient knowledge of 27 people. Research conducted by Ar-Rasily, Oktarisa Khairiyah; Dewi, and Puspita Kusuma in Semarang which stated that education is an activity or learning process to develop or improve certain abilities. The level of education also determines whether or not someone is easy to absorb and understand the knowledge they obtain, in general the higher one's education the better the knowledge ${ }^{(9)}$.

Based on the data obtained, the majority of respondents who have never received leprosy information have enough knowledge of 20 people. The results of this study are different from the results of Sari's research in Jakarta, which states that information will give effect to one's knowledge. If someone gets good information from various media such as $\mathrm{TV}$, radio or newspapers then it will be able to increase one's knowledge ${ }^{(10)}$. Based on the data obtained that the majority of people who have moderate stigma are young adults (20-29 years) as many as 27 people. The results of this study are in line with the results of the study of Tabah et al. in Cameroon, which states that the stigma against leprosy is worse in the environment of young adult people, than the youth and elderly community. At adulthood someone can choose their own decisions. A young adult is a productive age for a person to make every decision from what he knows and what he believes ${ }^{(11,12)}$.

Based on the data obtained that the majority of female respondents have more moderate stigma of 36 people. The results of this study are in line with the results of research by Kaehler et al. in Thailand, which states that stigma against leprosy is worse in women, than men. This is because women have a worse sense of concern such as Hastjarjo's research in Jogjakarta, which states women have complicated thoughts that cause this bad anxiety caused by hormones that are increased or released at certain times ${ }^{(13,14)}$. Based on data obtained that people who do not have a family history of leprosy have more moderate stigma as many as 55 people. The results of this study are in line with the results of the study of Adhikari et al. in Nepal, which states that stigma against leprosy is worse in people who have no family history of leprosy, than people who have a family history of leprosy ${ }^{(15)}$.

Based on the data obtained that people who have no history of neighbors with leprosy have more moderate stigma as many as 41 people. The results of this study are in line with the results of the study of Adhikari et al. in Nepal, which states that stigma against leprosy is worse in people who have no history of leprosy, than people who have a history of leprosy ${ }^{(15)}$. Based on the data obtained that people who have the latest high school / vocational education have more stigma are 35 people, 12 good people and 11 bad people. The results of this study are different 
from those of Adhikari et al. in Nepal, and Kaehler et al. in Thailand, which states that stigma against leprosy is worse in people who have primary education, than people who have secondary education and high school ${ }^{(13,15)}$. Based on the data obtained that people who have private jobs have more stigma are 20 people, 5 people good stigma and 5 people bad stigma.

The results of this study are different from the research of Adhikari et al. in Nepal and Kaehler et al. in Thailand, which states that stigma against leprosy is worse in people who do not have jobs and work as farmers, than people who have private work and public servants ${ }^{(13,15)}$.

Table 1. Characteristics of Respondents' Knowledge

\begin{tabular}{|c|c|c|c|c|c|c|c|}
\hline \multirow[b]{3}{*}{ No } & \multirow[b]{3}{*}{ Respondent Variable } & \multicolumn{6}{|c|}{ Community Knowledge } \\
\hline & & \multicolumn{2}{|c|}{ Deficient } & \multicolumn{2}{|c|}{ Sufficient } & \multicolumn{2}{|c|}{ Good } \\
\hline & & $(\mathbf{N})$ & $(\%)$ & $(\mathbf{N})$ & $(\%)$ & $(\mathbf{N})$ & $(\%)$ \\
\hline \multirow[t]{5}{*}{1.} & Last Education & & & & & & \\
\hline & Elementary school & 2 & $40 \%$ & 3 & $60 \%$ & 0 & $0 \%$ \\
\hline & Middle School & 4 & $33 \%$ & 5 & $42 \%$ & 3 & $25 \%$ \\
\hline & High School & 13 & $22 \%$ & 27 & $47 \%$ & 18 & $31 \%$ \\
\hline & Bachelor degree & 3 & $12 \%$ & 14 & $56 \%$ & 8 & $32 \%$ \\
\hline \multirow[t]{8}{*}{2.} & Sources of Community Knowledge & & & & & & \\
\hline & General Practitioners and Health & 0 & $0 \%$ & 2 & $33 \%$ & 4 & $67 \%$ \\
\hline & Hospital & 0 & $0 \%$ & 4 & $50 \%$ & 4 & $50 \%$ \\
\hline & Other Health Facilities & 0 & $0 \%$ & 6 & $75 \%$ & 2 & $25 \%$ \\
\hline & Internet & 0 & $0 \%$ & 2 & $33 \%$ & 4 & $67 \%$ \\
\hline & Friends / Family & 2 & $20 \%$ & 6 & $60 \%$ & 2 & $20 \%$ \\
\hline & TV / Newspaper / Radio & 3 & $13 \%$ & 9 & $37 \%$ & 12 & $50 \%$ \\
\hline & Never Receive Information about & 17 & $45 \%$ & 20 & $52 \%$ & 1 & $3 \%$ \\
\hline
\end{tabular}

Table 2. Description of Characteristics of Community Stigma

\begin{tabular}{|c|c|c|c|c|c|c|c|}
\hline \multirow[b]{3}{*}{ No } & \multirow[b]{3}{*}{ Respondent Variable } & \multicolumn{6}{|c|}{ Community Stigma } \\
\hline & & \multicolumn{2}{|c|}{ Good } & \multicolumn{2}{|c|}{ Moderate } & \multicolumn{2}{|c|}{ Bad } \\
\hline & & $(\mathbf{N})$ & $(\%$ & $(\mathbf{N})$ & $(\%)$ & $(\mathbf{N}$ & $(\%)$ \\
\hline \multirow[t]{5}{*}{1.} & Age & & & & & & \\
\hline & $20-29$ & 9 & 17 & 37 & $71 \%$ & 6 & $12 \%$ \\
\hline & $30-39$ & 3 & 14 & 13 & $62 \%$ & 5 & $24 \%$ \\
\hline & $40-49$ & 5 & 26 & 10 & $53 \%$ & 4 & $21 \%$ \\
\hline & $50-60$ & 2 & 26 & 3 & $37 \%$ & 3 & $37 \%$ \\
\hline \multirow[t]{3}{*}{2.} & Gender & & & & & & \\
\hline & Male & 9 & 21 & 27 & $61 \%$ & 8 & $18 \%$ \\
\hline & Girl & 10 & 18 & 36 & $64 \%$ & 10 & $18 \%$ \\
\hline \multirow[t]{2}{*}{3.} & Family History of Leprosy & & & & & & \\
\hline & Yes & 0 & $0 \%$ & 1 & 100 & 0 & $0 \%$ \\
\hline
\end{tabular}


Received : 2020-04-30 Revised : 2020-10-08

Acceptance : 2020-10-10 Publish : 2020-12-07

\begin{tabular}{ccccccc} 
Not & 19 & 21 & 55 & $60 \%$ & 18 & $19 \%$ \\
Do not know & 0 & $0 \%$ & 7 & 100 & 0 & $0 \%$ \\
4. History of Leprosy in the & & & & & & \\
Yes & 0 & $0 \%$ & 2 & 100 & 0 & $0 \%$ \\
Not & 13 & 19 & 41 & $59 \%$ & 15 & $22 \%$ \\
Do not know & 6 & 21 & 20 & $69 \%$ & 3 & $10 \%$ \\
5. & & & & & & \\
Elementary school & 1 & 20 & 3 & $60 \%$ & 1 & $20 \%$ \\
Middle School & 1 & $8 \%$ & 10 & $84 \%$ & 1 & $8 \%$ \\
High School & 12 & 21 & 35 & $60 \%$ & 11 & $19 \%$ \\
Bachelor degree & 5 & 20 & 15 & $60 \%$ & 5 & $20 \%$ \\
Profession & & & & & & \\
Farmers & 0 & $0 \%$ & 0 & $0 \%$ & 1 & 100 \\
Civil Servants & 2 & 20 & 6 & $60 \%$ & 2 & $20 \%$ \\
Private Work & 5 & 16 & 20 & $68 \%$ & 5 & $16 \%$ \\
Student / Student & 5 & 26 & 11 & $58 \%$ & 3 & $16 \%$ \\
Housewife & 4 & 14 & 19 & $68 \%$ & 5 & $18 \%$ \\
Does not work & 3 & 25 & 7 & $58 \%$ & 2 & $17 \%$ \\
\hline
\end{tabular}

Correlation analysis of public knowledge with the stigma of leprosy in Samarinda using Somer's d correlation test. Somer's d test results can be seen in table 3. Based on the results of our study, we found that the majority of people in Samarinda City have sufficient knowledge with moderate stigma. The analysis results obtained a value of $\mathrm{P}=0.456$ which means that there is no relationship between community knowledge and the stigma of leprosy in Samarinda City. This was also found by Caroline's research at the University of Indonesia. In that study, Caroline and her team revealed that the cause of stigma was not because of lack of knowledge, but because of the clinical manifestations seen in leprosy sufferers ${ }^{(16)}$.

Table 3. Bivariate Test Results of Relationships between Community Knowledge and Stigma Against Leprosy in Samarinda City

\begin{tabular}{cccccccccc}
\hline Community & \multicolumn{4}{c}{ Community Stigma } & \multicolumn{2}{c}{ Total } & \multirow{2}{*}{$\mathrm{P}$} \\
\cline { 2 - 8 } Knowledge & \multicolumn{3}{c}{ Bad } & \multicolumn{4}{c}{ Moderate } & \multicolumn{3}{c}{ Good } & & \\
\cline { 2 - 9 } & $\mathrm{N}$ & $\%$ & $\mathrm{~N}$ & $\%$ & $\mathrm{~N}$ & $\%$ & $\mathrm{~N}$ & $\%$ \\
\hline Deficient & 3 & 3 & 16 & 16 & 3 & 3 & 22 & 22 \\
Sufficient & 9 & 9 & 29 & 29 & 11 & 11 & 49 & 49 & \\
Good & 7 & 7 & 18 & 18 & 4 & 4 & 29 & 29 & \multirow{2}{*}{0,456} \\
\hline Total & 19 & 19 & 63 & 63 & 18 & 18 & 100 & 100 \\
\hline
\end{tabular}

Having adequate knowledge does not always lead to a good attitude towards leprosy. Therefore, education that only emphasizes the facts that leprosy can be cured is not enough to eliminate the existing stigmatization. In addition to knowledge, increasing empathy, interaction 
and improving perceptions about leprosy also play an important role in improving stigma. The stigma itself is closely related to the manifestations caused by leprosy. Stigma would not have been possible had it not been for the misunderstanding caused by the personal assumption that leprosy would inevitably cause disability. Basically, visible manifestations or deformities can be prevented by early treatment. However, sufferers are generally afraid to report their illness because they are afraid of being able to stigmatize. The longer they seek treatment, the more severe the illness, the greater the stigma they suffer. This creates a vicious cycle between stigmatization and leprosy elimination programs. Therefore, education and health promotion must also emphasize self-awareness to report symptoms early. This needs to be supported by the community, which can also be generated by education and health promotion. In this way, it is hoped that it can end the vicious cycle of stigmatization.

Caroline also suggested several ways to overcome the stigma against leprosy, including:

1. Treat leprosy through integrated health services.

2. Enhancing public education through cultural and religious beliefs.

3. Change the perception of leprosy.

4. Counseling to help leprosy patients deal with their disease problems, avoid selfstigmatization, and face discrimination.

5. Promote the positive attitude and empathy of health workers who can influence how patients and the community receive leprosy.

Just increasing knowledge is not enough to overcome the stigma associated with attitudes, feelings, and behavior towards leprosy. Education that aims to increase knowledge, must consist not only of disease, but also of how to increase empathy for leprosy patients, not afraid to interact with them and how to encourage those who suffer from the initial manifestations to get early treatment. With earlier treatment, it is expected to prevent defects that lead to worse stigmatization $^{(16)}$.

\section{CONCLUSION}

The conclusion obtained based on the results and discussion that has been described is that there is no relationship between community knowledge and the stigma of leprosy in Samarinda City. Respondents who participated in this study were dominated by women, aged 20-29 years, private work, the last high school / vocational education, and did not have a history of leprosy in the family or the surrounding environment. 


\section{REFERENCES}

1. Kementerian Kesehatan Republik Indonesia. Info Datin Pusat Data dan Informasi Kementerian Kesehatan Republik Indonesia. 2015;(Maret):1-8.

2. Kementerian Kesehatan Republik Indonesia. Pedoman Nasional Program Pengendalian Penyakit Kusta. Jakarta: Kementerian Kesehatan Republik Indonesia; 2012.

3. Umaya, Adi MS, Saraswati LD. Gambaran status kecacatan kusta pada penderita kusta Di Kabupaten Blora. J Kesehat Masy. 2016;4(4):496-502.

4. Kementerian Kesehatan Republik Indonesia. Data dan Informasi - Profil Kesehatan Indonesia. 2018;1-184.

5. Soedarjatmi; Istiarti, Tinuk; Widagdo L. Faktor-faktor Yang Melatarbelakangi Persepsi Penderita Terhadap Stigma Penyakit Kusta. J Promosi Kesehat Indones. 2009;18-24.

6. Liliweri A. Dasar-Dasar Komunikasi Kesehatan. Yogyakarta: Pustaka Pelajar; 2007.

7. Notoatmodjo S. Pendidikan dan Perilaku Kesehatan. Jakarta: Rineka Cipta; 2003.

8. Tarigan NP. Masalah Kusta Dan Diskriminasi Serta Stigmatisasinya Di Indonesia. Humaniora. 2013;432-44.

9. Ar-Rasily, Oktarisa Khairiyah; Dewi PK. Faktor-Faktor yang Mempengaruhi Tingkat Pengetahuan Orang Tua Mengenai Kelainan Genetik Penyebab Disabiltas Intelektual di Kota Semarang. J Kedokt Diponegoro. 2016;1422-33.

10. Sari REP. Hubungan Antara Tingkat Pendidikan dengan Pengetahuan Wanita tentang faktor Resiko Kanker Payudara di RW 02 Kompleks Taman Rempoa Indah. Jakarta: Universitas Islam Negeri Syarif Hidayatullah; 2010.

11. Tabah, Earnest Njih; Nsagha, Dickson Shey; Bissek, Anne-Cecile Zoung-Kanyi; Njamnshi, Theophilus Ngeh; Njih, Irine Ngani-Nformi; Pluschke, Gerd; Njamnshi AK. Community knowledge, perceptions and attitudes regarding leprosy in rural Cameroon: The case of Ekondotiti and Mbonge health districts in the South-west Region. PLoS Negl Trop Dis. 2018;1-17.

12. Wawan, A.; Dewi M. Teori dan Pengukuran Pengetahuan, Sikap, dan Perilaku Manusia. Yogyakarta: Nuha Medika; 2010.

13. Kaehler, Nils; Adhikar, Bipin; Raut, Shristi; Marahatta, Sujan Babu; Chapman RS. Perceived Stigma towards Leprosy among Community Members Living Close to Nonsomboon Leprosy Colony in Thailand. PLoS One. 2015;1-11.

14. Hastjarjo TD. Mengintegrasikan Psikologi Wanita. Yogyakarta: FP UGM; 2008.

15. Adhikari, Bipin; Kaehler, Nils; Chapman, Robert S.; Raut, Shristi; Roche P. Factors Affecting Perceived Stigma in Leprosy Affected Persons in Western Nepal. PLoS Negl Trop Dis. 2014;1-8.

16. Puspita CG, Widjaja FF. Stigma Towards Leprosy Among Medical Students. Maj Kedokt Indones. 2011;61(Januari):20-4. 